\title{
FDI TRENDS AND CHARACTERISTICS IN KOSOVO
}

\author{
Arben SAHITI ${ }^{1}$, Ard AHMETI ${ }^{2}$, Arbana SAHITI ${ }^{3}$ \\ ${ }^{1}$ University "Kadri Zeka" Gjilan, Faculty of Economics, Gjilan 60000, Kosovo \\ ${ }^{2,3}$ University of Prishtina, Faculty of Economics, Prishtinë 10000, Kosovo
}

Corresponding author’s e-mail: ardisahmeti@gmail.com

\begin{abstract}
In recent years, Kosovo has had a strong volatility in attracting foreign investment into the domestic market, which has been accompanied not only by the decline in FDI flows but also by the quality of investments. Kosovo has not been able to catch the trend of FDI absorption just as it takes place in an important part of developing economies; it is also failing to follow the success of neighbouring countries. The success of further development of Kosovo's economy cannot be imagined without the strong presence of foreign-owned businesses as a guarantee that this goal will become objectively achievable. The aim of the study is to examine recent trends and characteristics of FDI flows and patterns in Kosovo. This study adopts a qualitative research method using secondary data taken mainly from Kosovo's Central Bank and Business Registration Agency. The present study concludes that FDI in Kosovo is mainly oriented to the Real Estate, Rental and Business sectors. Moreover, the main FDI contributors are businesses from the EU countries and Turkey. A majority of FDI inflows in Kosovo have been predominantly dominated by five countries.
\end{abstract}

Keywords: Business, developing countries, economic activity, sector, foreign direct investment (FDI).

\section{INTRODUCTION}

For the past decade, Kosovo has been among the fastest growing economies in the Balkans. The pattern of rapid development has been fuelled by government expenditures, large amount of remittances from Albanian diaspora, financial aid and technical expertise and support from various international organisations. Outsourcing is booming in Kosovo. Its young and talented youth is pushing the country to be specialised in the IT related field where lately many local companies have been established which provide services for renowned international corporations in Western Europe and the USA. Having laid down appropriate macro-economic policies, further prosperity for economic growth is very bright in Kosovo. However, the drawback includes the fact that the current pattern of development does not absorb a large number of the labour force unlike manufacturing based industries.

The Republic of Kosovo, despite the many challenges it has faced, has managed relatively well to address the importance of FDI in addition to consolidating state institutions. This process is ongoing, and remains very challenging given the ever-increasing competition at the regional level and beyond; the continued focus and efforts to strengthen international subjectivity as well as the continued demands of Western allies to normalise relations with the state of 
Serbia to conclude open issues. Moreover, a number of factors have contributed to Kosovo's failure to persuade more foreign-owned companies to target its market, including: weak rule of law, lack of good governance political instability, corruption, and the level of informal economy.

The main aim of the present research is to analyse FDI trends and characteristics in Kosovo. The study will also examine FDI distribution by sectors, by country of origin, and businesses with foreign ownership. Qualitative research is used in the research based on secondary data derived from Kosovo's Central Bank and Business Registration Agency.

\section{LITERATURE REVIEW}

For years, a dynamic, sophisticated and uncompromising race has been underway between states and regions internationally to attract foreign capital into their countries. The dimension and scope to dominate this challenge are becoming increasingly difficult as countries around the world are using all available resources and all their political and economic power to lure investors. This is because foreign direct investment (FDI) plays an important role for sustainable development, especially for developing countries (De Schutter et al., 2012). In one way or another, a vast majority of countries aiming for accelerated growth of their economies have been dependent on foreign capital investment regardless of the market size or its development (Sahiti et al., 2017), and it is almost unimaginable that such a thing would be accomplished nowadays without addressing this form of investment. Host countries adopt friendly FDI policies and provide different incentives to meet investors' expectations (Sahiti et al., 2018).

In the past two decades, multinational corporations (MNCs) have focused their investments on developing countries, which are rich in natural resources and abundant in raw materials. This situation has created a viable financial opportunity not only for these countries but also for businesses given the high prices of goods (Barclay, 2012). It is considered that natural resources alone are not sufficient for FDI to occur because natural resources do not bring comparative advantages. Therefore, FDI in the search for resources includes costs, labour quality, infrastructure, construction and land costs (Drogendijk \& Blomkvist, 2013).

There are a significant number of benefits resulting from the arrival of foreignowned businesses in the host countries including: years of experience in doing business, technical and professional experience, technology, machinery, advanced distribution lines, and image (Zarsky, 2004). It has also been well documented that FDI contributes significantly to a nation's economic growth as it promotes employment, ensures knowledge transfer and generates diffusion of technology and productivity in the host country (World Bank Group, 2018). The importance of FDI has mobilised developing countries to create a business environment that is attractive to multinational corporations, and has driven these states to adapt their government policies to attract foreign investors. In this form, many financial and economic reforms have been implemented, including the implementation and adoption of investment and trade policies. This has contributed to the fact that most countries in the world are subject to FDI (Economou et al., 2017). 
The reasons why MNCs invest in their respective countries are different, and vary from corporation to corporation depending on the industry they operate in, the size of the markets they target, their geographic position, natural resources, human capital, investment policies and fiscal and tax incentives. Options to invest are thoroughly evaluated by businesses and the advantages and disadvantages of any solution that follows are meticulously analysed, as all real parameters are considered (Dunning and Lundan, 2008). As a consequence, countries from restrictive regimes in relation to foreign capital have gradually shifted to more liberal policies to encourage investors, while at the same time have attempted to protect vital sectors of the economy from falling into total control of capitalists from other foreign countries (Muchlinski et al., 2008).

Countries aiming to attract foreign direct investments into their markets tend to provide MNCs with what they require and, in this context, shape their FDI policy to meet and exceed the needs and expectations of potential investors. Understanding the motivation is essential to understanding why MNCs choose a particular host country among many other alternatives given the ever-increasing competition to attract foreign investors globally. Thus, knowledge of motivations enables policymakers to be more proactive and alert in this regard.

\section{METHODOLOGY}

The methodology approach plays a very integral part in the quality of research (Saunders et al., 2012). This study is a desk research making use of secondary data. Using secondary data carriers both advantages and limitations. The advantages comprise saving resources, including both time and money. Secondary data are also of high quality and collecting this data can prove very difficult if not impossible for some scenarios (Lomas, 2011). Secondary data provide a viable alternative to be checked for accuracy and reliability by others, unlike primary data, because they are open to public for any further inquiry or contest. The key disadvantages relate to issues of control and quality because secondary data can be outdated or already generated for other purposes and may not meet the specific needs of a given study as shown by Saunders et al. (2012).

Analysis of documents and material has been carried out on some Kosovo's government publications and statistics. Interpretive method has been used to analyse the data. The most common analysis of qualitative data is observer impression, a situation where the investigator observes and examines the data, interpret them via forming an impression and report their impression in a structured and sometimes quantitative form. The study makes use of tables and figures to describe the FDI trends and characteristics in Kosovo.

\section{FDI IN KOSOVO}

Foreign direct investment in the Republic of Kosovo is regulated under Law No. 04/L-220 on Foreign Investment (2014). The law aims at regulating the protection, promotion and encouragement of foreign investments in the Republic of Kosovo. Its objective is also to provide foreign investors with fundamental rights 
and guarantees that provide assurance to foreign investors that their investments are protected and treated in a manner fair in accordance with internationally accepted standards and practices. Fig. 1 shows FDI in Kosovo by years (20062017), in millions of euros.

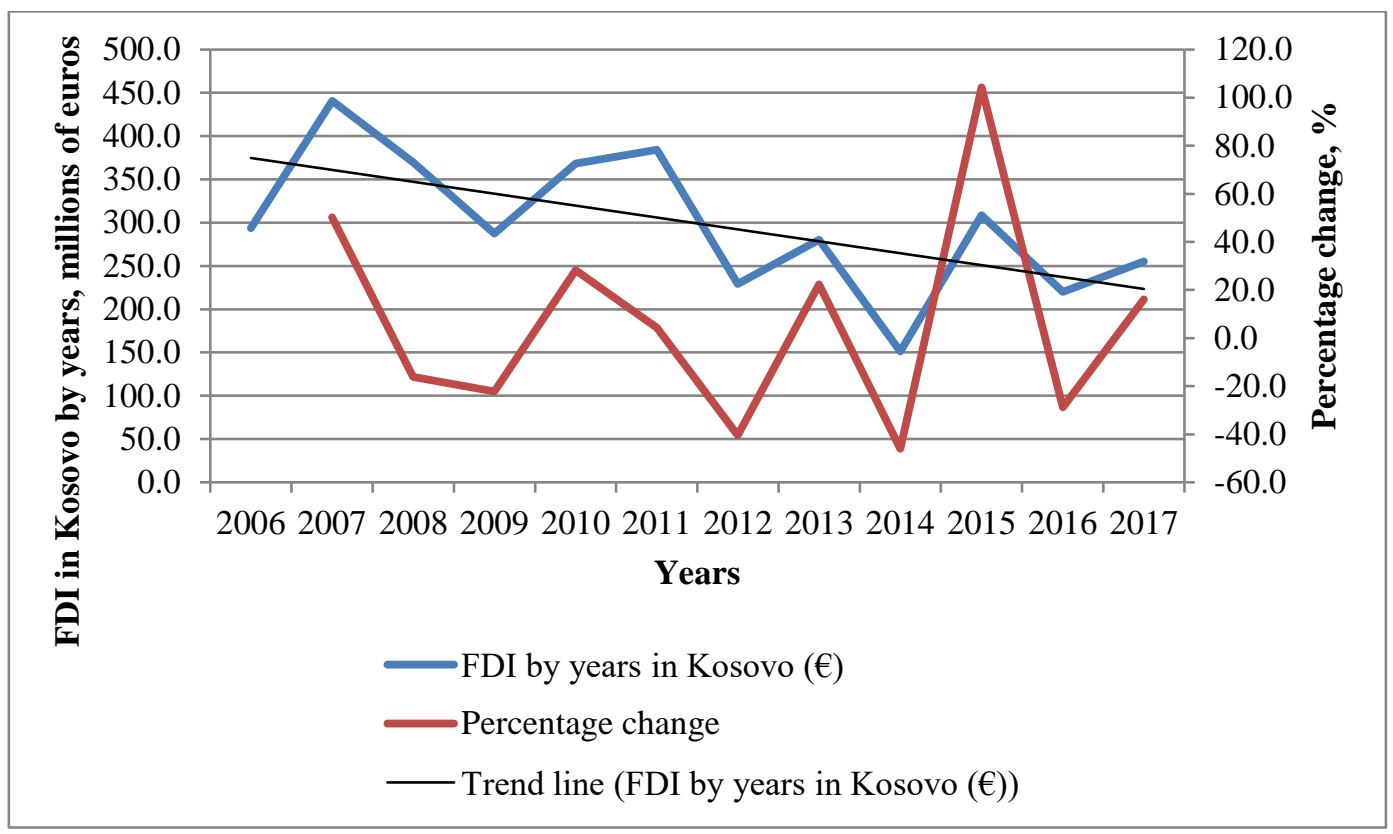

Fig. 1. FDI in Kosovo by years, 2006-2017, in millions of euros (developed by the authors based on CBK data, 2018).

During the period of 2006-2017 as shown in Fig.1 (blue curve), total FDI in Kosovo reached around 3.6 billion euros. In recent years due to the European economic crisis, internal political problems, the fragility of state institutions, the perception of high levels of corruption, inefficiencies of justice institutions, there has been a sharp decline in the level of FDI flows in Kosovo. This is especially the case from 2012 to 2014, but fortunately this negative trend was broken in 2015 , where the total amount of FDI amounted to 308.8 million euros. The highest level of FDI was in 2010 at EUR 368.5 million, while the lowest at EUR 151.2 million in 2014.

As shown in Fig. 1 (red curve), the average total change in FDI flows over 12 years was $71.8 \%$ and after dividing the amount gained by the number of years, the average increase in FDI inflows was only $5.98 \%$. The graph line that reflects FDI flows over the years in Kosovo shows that the fluctuations have been very large, with a downward trend for the high period mentioned. This is seen from the average FDI change over the years as well as from the trend line as shown in the graph above. This is quite alarming and should serve as a signal that this topic receives the attention of policymakers to support sustainable development. The average changes over the years and the downward trend make it very difficult to predict the likely future FDI flows in Kosovo. 


\section{FDI IN KOSOVO BY ECONOMIC ACTIVITY}

Table 1 shows the figures of FDI flows in Kosovo for the period of 2007-2017 by economic activity. As can be seen, there is a great discrepancy between the sectors in terms of foreign capital distribution. In fact, the majority of FDI is mainly concentrated in the real estate, leasing and business sectors with $36.7 \%$ or over EUR 1.2 billion. The financial service is the subsequent sector that attracted FDI within this period by $17.2 \%$ or EUR 566 million. Other sectors that dominate FDI flows are industry with 11.2 (EUR 370 million), construction with $10.6 \%$ (or about EUR 350 million) and transport \& communications with $8 \%$ (or about EUR 266.4 million).

Table 1. FDI in Kosovo by Economic Activity, in millions of euros (CBK, 2018)

\begin{tabular}{|c|c|c|c|c|c|c|c|c|c|c|c|}
\hline Sector & 2007 & 2008 & 2009 & 2010 & 2011 & 2012 & 2013 & 2014 & 2015 & 2016 & 2017 \\
\hline Agriculture & 7.9 & 8.5 & 13.1 & 0.9 & 0.6 & 0.3 & 0.4 & 0.2 & 1 & 1.2 & -1.3 \\
\hline Mines & 41.5 & 17.4 & 7 & 17.7 & -5.2 & -25 & -14.1 & 4.2 & -36.9 & -19.1 & -4.9 \\
\hline Industry & 74.8 & 53.7 & 57.6 & 101.1 & 46.9 & 27.4 & 11.5 & -34 & 20.7 & 4.6 & 5.7 \\
\hline Energy & 2.5 & 16.7 & 8.7 & - & 0.2 & 2.2 & 48.8 & 13.4 & 11.9 & 3.4 & -1 \\
\hline Construction & 5.2 & 13.5 & 35.5 & 54.2 & 133.1 & 31.1 & 17.3 & -19.9 & 46.3 & 28.2 & 5 \\
\hline Trading services & 12.7 & 10.1 & 16.2 & 6.8 & 11.6 & 9.3 & 14.6 & 8.4 & 12 & 14.5 & 10.3 \\
\hline $\begin{array}{l}\text { Hotels and } \\
\text { Restaurants }\end{array}$ & 12.7 & 2.1 & 2.4 & - & 0.2 & 0.5 & 0.8 & 0.4 & - & 0.7 & 0.8 \\
\hline $\begin{array}{l}\text { Transportation } \\
\text { and } \\
\text { Communication }\end{array}$ & 129.2 & 51 & 21.9 & -15.9 & 29 & 32.4 & 51 & -9.1 & -6.1 & -9.1 & -7.9 \\
\hline Financial services & 102 & 109.6 & 75.3 & 39.4 & 33 & 22.4 & 4.4 & 41.9 & 64.3 & 19 & 55 \\
\hline $\begin{array}{l}\text { Real estate, } \\
\text { Leasing and } \\
\text { business activities }\end{array}$ & 30.9 & 62.2 & 43.9 & 75.5 & 60.5 & 115.7 & 136.1 & 142.1 & 189.6 & 167.6 & 187.2 \\
\hline Other services & 4.5 & 2.1 & 2.7 & 1.3 & 11.3 & 1.8 & 3.3 & 2.2 & 4.5 & 9.4 & 4.9 \\
\hline Other activities & 16.9 & 23 & 3.2 & 87.6 & 63.2 & 11 & 6.2 & 1.4 & 1.4 & -0.6 & 1.6 \\
\hline Total & 440.7 & 369.9 & 287.4 & 368.5 & 384.4 & 229.1 & 280.2 & 151.2 & 308.8 & 220 & 255.4 \\
\hline
\end{tabular}

The overview of FDI by economic activity shows that at times some sectors have faced withdrawal of part of the investments from the Kosovo market, where in this context, to the greatest extent, the mining sector worth around 105.2 million euros and transportation and communication worth 48.1 million euros have been affected.

FDI in Kosovo by country of origin is described further.

\section{FDI IN KOSOVO BY COUNTRY OF ORIGIN}

According to Fig. 2, investors are mainly from the EU countries dominating as the main contributors to FDI in Kosovo. The top five (5) major countries 
contributing to Kosovo's FDI include Germany, Switzerland, Turkey, the UK, and Austria. Businesses in these countries have pumped about 2 billion euros into the Kosovo economy, or $59.13 \%$ of total investment. During the period of 2007-2017, German businesses were the main investors in Kosovo with EUR 552.6 million investment or $16.77 \%$.

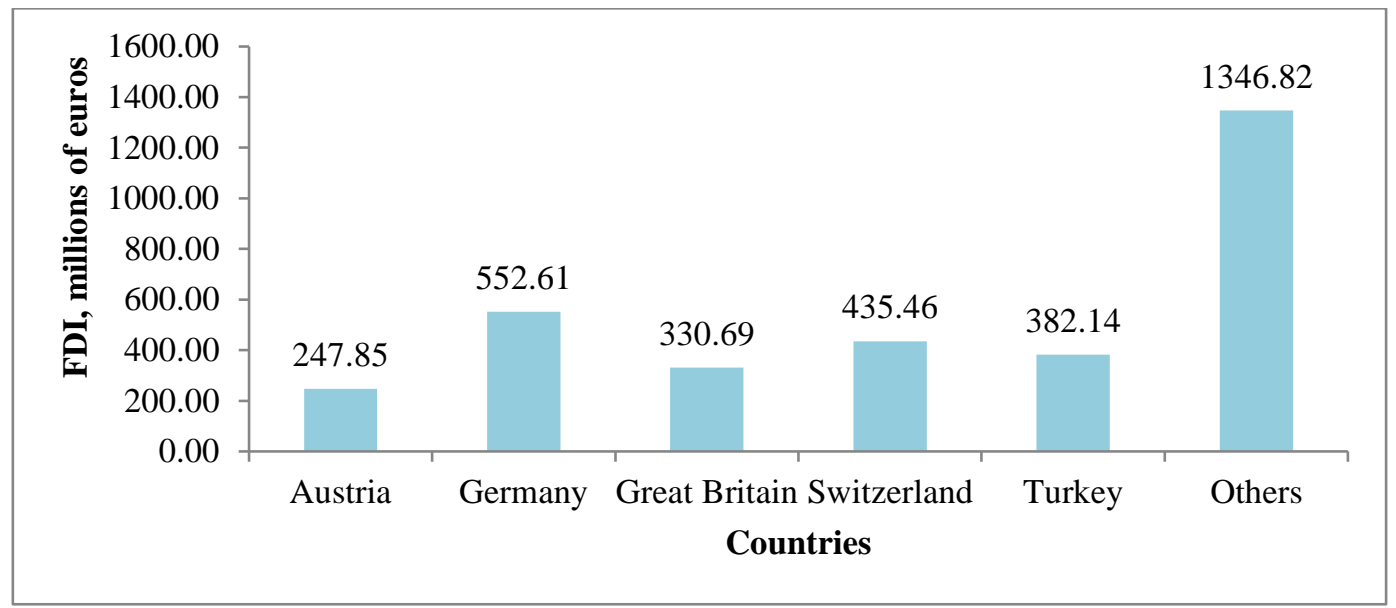

Fig. 2. FDI by top 5 countries and others, 2007-2017, in millions of euros (developed by the authors based on CBK data, 2018).

The countries where these businesses come from had also long contributed politically to all the processes that Kosovo went through before and after 1999. Another important reason that has potentially driven the level of FDI out of these states is the strong diaspora and their links with Kosovo. Businesses from other countries that have invested in Kosovo are from Slovenia and Albania, both of which have almost the same level of investment with a difference of only about 2 million euros. It is also worth noting that US businesses also invested 156.7 million euros or $4.75 \%$ of total investments during this period.

\section{BUSINENESSES WITH FOREIGN OWNERS}

According to data from the Kosovo Business Registration Agency (KBRA, 2018) operating within the Ministry of Trade and Industry, in Kosovo from 2003 to 2016, a total of 5765 foreign-owned businesses were registered. A vast majority of them, about $80 \%$ are registered in only four sectors: trade $(36.72 \%)$, services $(15.35 \%)$, manufacturing $(13.76 \%)$, and construction $(12.35 \%)$. It means that these economic sectors are more attractive to foreign investors as they have directed investment there.

Such a large share in trade is not that it has an impact on employment and sustainable economic development, as the money that exists in the Kosovo market is transferred to other countries from which the trade comes. Necessarily, forms must be found and investment policies designed to encourage these businesses to switch to production. 
Investments in construction have also only a short-term effect and, therefore, they generate a lot of profit. The number of businesses registered over the years has been fluctuating (see Fig. 3). The upward trend was from 2006 to 2008, reaching a peak of 638 businesses, and then there was a slight decline that continued until 2014 where the number of registered businesses was 149. Then, the situation significantly improved in 2015-2016. Fig. 3 shows the number of businesses with foreign capital registered by years (2003-2016).

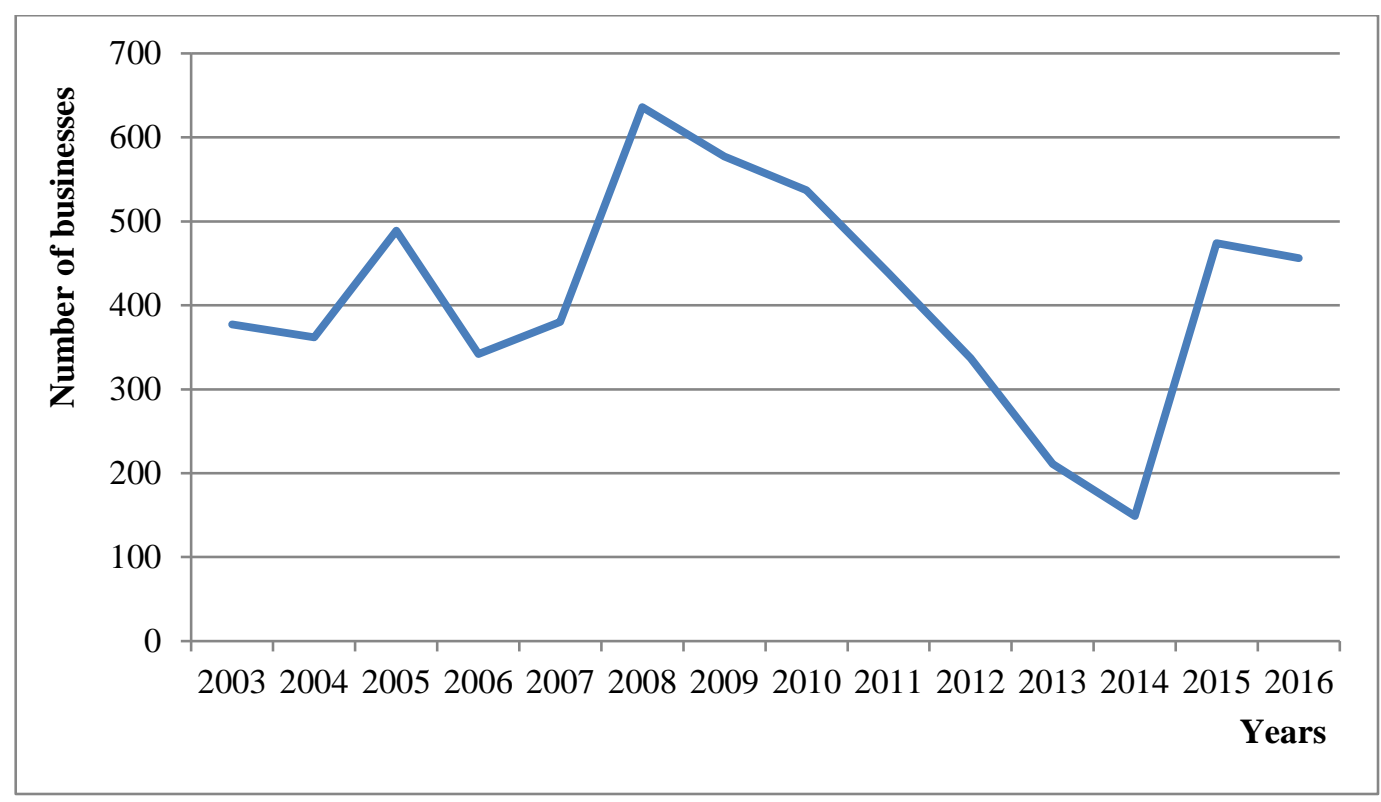

Fig. 3. Number of businesses with foreign capital registered by years, 2003-2016 (developed by the authors based on KBRA data, 2017).

It is worth noting that during the onset of the global financial crisis which began in 2007 with subprime mortgages in the US and lasted until 2011 with the decline in the US debt rating (Elliot, 2011), many large corporations in the world restrained their investments in the American and European markets for the following years. During this period, business activity declined and this automatically affected their financial performance. However, during these years, despite the crisis, the number of foreign-owned businesses in Kosovo steadily increased.

There are several reasons why the Kosovo market was immune and attracted foreign investors. The first was economic growth in Kosovo during the period of the global financial crisis. Second, Kosovo's commercial banks offered only commodity products and, therefore, were not affected by shocks and turbulence in global markets due to low exposure and impact on the international financial system. Fig. 4 shows the number of foreign-owned businesses by the top 10 countries in Kosovo. Of the total number of businesses registered during the period of 2003-2016, about $71 \%$ of them originated from these countries. Albania tops the list with 841 businesses followed by Turkey with 702 and Macedonia with 578 . 


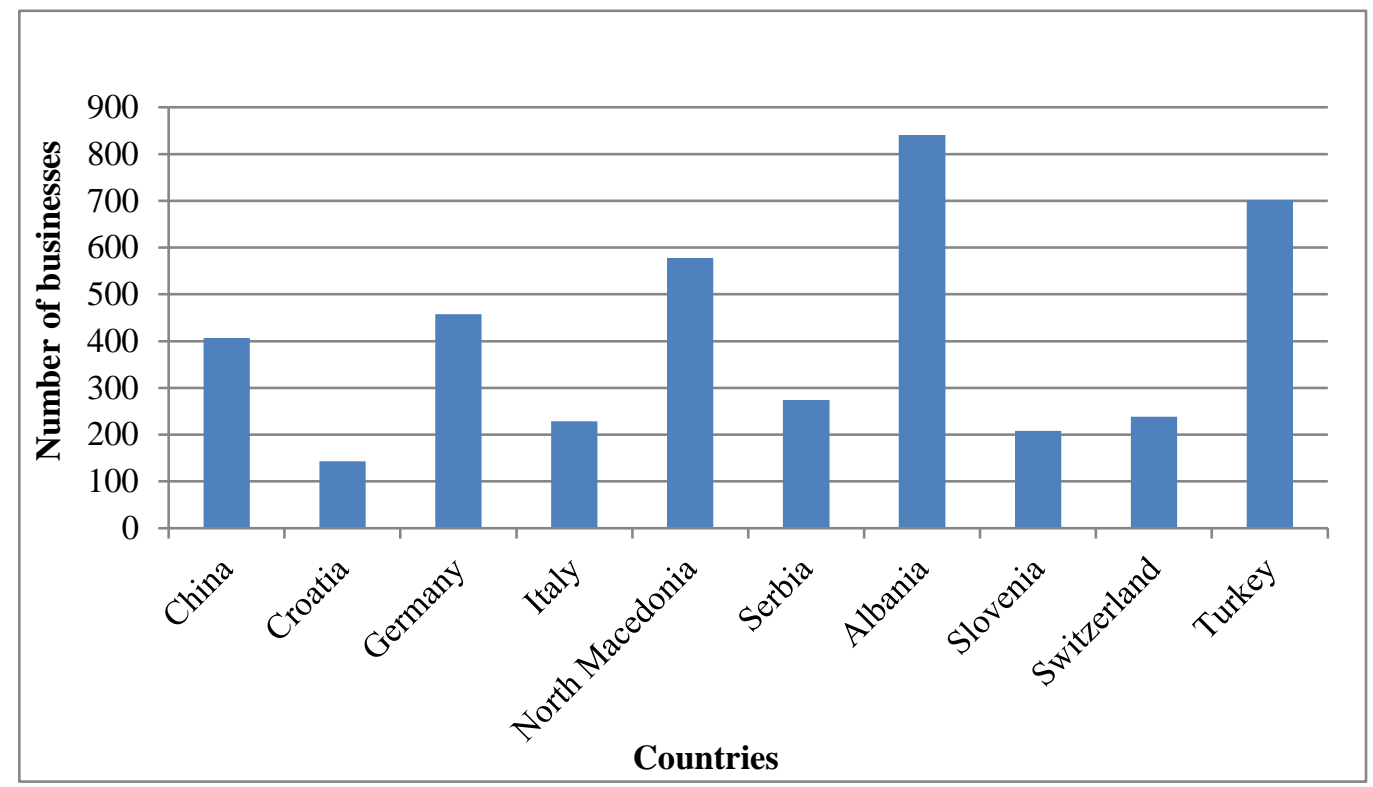

Fig. 4. Number of businesses with foreign owners by top 10 countries, 20032016 (developed by the authors based on KBRA data, 2017).

In the top 10 countries from which registered businesses originate, only three are part of the European Union (EU), i.e., Italy, Croatia, and Slovenia.

In addition, China ranks among the five countries with the largest number of businesses operating in Kosovo. Massive penetration of Chinese businesses is taking place everywhere in the region and Europe, and Kosovo has become a target of their outreach and preferred destination.

Looking at Fig. 4, we see the dominance of the Western Balkan countries in the number of businesses, with the exception of Montenegro and Bosnia and Herzegovina, all other states that were part of Yugoslavia are part of this ranking. There are several reasons why we have this ranking. First, the states that were part of the former Yugoslavia have established business ties with Kosovo from the past, and therefore know the mentality, culture, taste and circumstances of the Kosovo market very well. Second, these states also have geographical proximity. Businesses registered in Germany and Switzerland are largely driven by the strong presence of the Albanian Diaspora living and operating there and the lobbying of influential people to bring in investors from these countries. Still, we do not have quality investments from powerful corporations from these states.

\section{CONCLUSION}

Attempts to achieve the desired outcomes for host countries regarding FDI remain very challenging given the fact that at the regional and international levels, competition is becoming increasingly powerful and difficult to control. Countries that aim at attracting companies with foreign capital are doing their best, leveraging all the potential to triumph. 
The Republic of Kosovo, after the end of the 1999 war and the creation of a provisional government to this day, despite the many challenges it has faced in the political, economic and security spheres, has also given importance to promoting foreign capital in the domestic market. The overview of FDI inflows into Kosovo shows that the government has been able to create different policies and frameworks at the macro-economic and micro-economic levels to facilitate the way of doing business and thus to attract foreign investors. However, the results show that in this context, Kosovo has registered little success in its bid to attract FDI.

The overall picture of FDI in Kosovo shows that in recent years there has been a great deal of instability due to the fact that fluctuations from year to year have been pronounced. This sign points to the deterioration of the situation, which must be addressed to stabilise the trend and bring it back on track. Otherwise, continuing the volatility will bring even worse consequences, scaring even the current investors. The bulk of FDI mainly focuses on the Real Estate, Rental and Business sectors. The financial service is the subsequent sector that has attracted FDI within this period.

Other sectors that have dominated FDI flows are Industry, Construction, Transportation and Communication. It is noteworthy that some sectors have faced the withdrawal of a portion of the investments from the Kosovo market, where in this context, the mining, transportation and communication sectors have been most affected. In terms of investment by country, capital from the European Union dominates, while the main countries from which foreign investors originate are Germany, Switzerland, Turkey, the UK, and Austria. These make up about $60 \%$ of the total investments made from 2007 to 2017.

In addition, the number of foreign-owned businesses registered in Kosovo has experienced significant fluctuations over the years. In 2008, the largest number was recorded for the mentioned period, and then the downward trend was from 2009 to 2014. In recent years, the situation has improved as the number of companies has increased. However, the quality of investment has declined due to the fact that in addition to franchises in gastronomy, reputable businesses from developed countries have not invested to date in Kosovo.

Foreign countries leading by number of businesses registered in Kosovo are from the Western Balkans, with the exception of Montenegro.

All other countries are in the top 10 of the countries from which their invested businesses originate. This is a very worrying trend and it represents a negative signal on the quality of FDI and the effects it may have on the Kosovo market.

\section{REFERENCES}

Barclay, L. A. (2012). Dependent Underdevelopment? Institutional Efficiency and FDI-facilitated Development in the Bauxite Industry of Suriname. Social and Economic Studies, 127-167. CBK. (2018). Central Bank of Kosovo. Time Series. Retrieved from www.bqk-kos.org/?id=55

De Schutter, O., Swinnen, J., \& Wouters, J. (Eds.). (2012). Foreign direct investment and human development. The law and economics of international investment agreements. London: Routledge. https://doi.org/10.4324/9780203076880

Dunning, J. H. and Lundan, S. M. (2008). Multination Enterprises and the Global Economy, 2nd Edition. Cheltenham: Edward Elgar Publishing Limited. 
Drogendijk, R., \& Blomkvist, K. (2013). Drivers and motives for Chinese outward foreign direct investments in Africa. Journal of African Business, 14(2), 75-84. https://doi.org/10.1080/15228916.2013.804320

Economou, F., Hassapis, C., Philippas, N., \& Tsionas, M. (2017). Foreign direct investment determinants in OECD and developing countries. Review of Development Economics, 21(3), 527-542. https://doi.org/10.1111/rode.12269

KBRA. (2018). Kosovo Business Registration Agency. Business register. Prishtina: Agency for Business Registration.

Law No. 04/L-220 on Foreign Investment. (2014). Assembly of Republic of Kosovo, Pristina, Kosovo. Retrieved from www.gzk.rks-gov.net/ActDetail.aspx?ActID=8982

Lomas, R. (2011). Mastering Your Business Dissertation: How to Conceive, Research and Write a Good Business Dissertation. London: Routledge.

Muchlinski, P., Ortino, F., \& Schreuer, C. (Eds.). (2008). The Oxford handbook of international investment law. Oxford University Press on Demand. https://doi.org/10.1093/oxfordhb/9780199231386.001.0001

Sahiti, A., Aliu, M., \& Sahiti, A. (2017). Review on Policy Developments of FDI in India. Acta Universitatis Danubius: Oeconomica, 13(1), 197-208.

Sahiti, A., Ahmeti, S., \& Ismajli, H. (2018). A review of empirical studies on FDI determinants. Baltic Journal of Real Estate Economics and Construction Management, 6(1), 1-11. https://doi.org/10.1515/bjreecm-2018-0003

Saunders, M. N. K., Lewis, P., \& Thornhill, A. (2012). Research methods for business students. Pearson Education Limited, Harlow. 741 p.

World Bank World Bank Group. (2017). Global Investment Competitiveness Report 2017/2018. Foreign Investor Perspectives and Policy Implications. World Bank Publications.

Zarsky, L. (Ed.). (2005). International investment for sustainable development: Balancing rights and rewards. Earthscan. 240 p.

\section{AUTHORS' SHORT BIOGRAPHIES}

Arben Sahiti, Dr., is an Assistant at the Faculty of Economics, University "Kadri Zeka" in Gjilan. He obtained the Master of Science degree in the field of Finance, Accounting, and Management from Bradford School of Management, University of Bradford in the United Kingdom, and the Bachelor of Science degree from Rochester Institute of Technology (RIT), the USA, with the major in Management and a minor in Public Policy. He has completed his Doctoral studies at the University of Prishtina, Faculty of Economics. He has participated in the international scientific conferences in Italy, Spain and Turkey. He is the author and co-author of several scientific publications. He has been a Board Member at the University "Kadri Zeka" in Gjilan and coordinator for the Faculty of Economics. E-mail: arben.sahiti@uni-gjilan.net ORCID iD: https://orcid.org/0000-0002-5429-7626

Ard Ahmeti, MSc, is an entrepreneur and independent researcher. He has finished both Bachelor and Master studies with distinction at the Faculty of Economics, Department of Banking, Finance and Accounting at the University of Prishtina. Currently, he works as an independent researcher and owns a private consulting firm based in Prishtina with the main focus on issues pertaining to accounting and finance.

E-mail: ardisahmeti@gmail.com

Arbana Sahiti, Dr. is currently working as an Assistant at the Department of Banking, Finance and Accounting, Faculty of Economics, University of Prishtina "Hasan Prishtina". Arbana's focus is research in risk management and accounting. Arbana has experience of more than 10 years participating in different international projects where, firstly, she got involved as one of the distinguished students of the university and later as the member of Faculty staff, she undertook short period mobility mainly at the European universities.

E-mail: arbana.sahiti@uni-pr.edu

ORCID iD: https://orcid.org/0000-0002-9669-5913 